\title{
Antimelanogenesis Effects of Fungal Exopolysaccharides Prepared from Submerged Culture of Fomitopsis castanea Mycelia ${ }^{\mathrm{S}}$
}

\author{
Juhui Jin ${ }^{1}$, Thi Thanh Hanh Nguyen ${ }^{2}$, Changmu Kim ${ }^{3}$, and Doman Kim ${ }^{1,2 *}$ \\ ${ }^{1}$ Graduate School of International Agricultural Technology, Seoul National University, Pyeongchang 25354, Republic of Korea \\ ${ }^{2}$ Institute of Food Industrialization, Institutes of Green Bio Science and Technology, Seoul National University, Pyeongchang 25354, \\ Republic of Korea \\ ${ }^{3}$ National Institute of Biological Resources, Incheon 22689, Republic of Korea
}

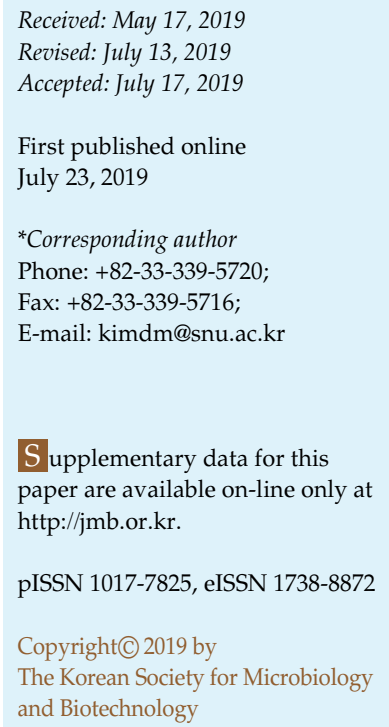

Fungal exopolysaccharides are important natural products having diverse biological functions. In this study, exopolysaccharides from Fomitopsis castanea mycelia (FEPS) were prepared, and the highest mushroom tyrosinase inhibitory activity was found. FEPS were prepared from cultivation broth by ethanol precipitation method. The extraction yield and protein concentration of FEPS were $213.1 \mathrm{mg} / 1$ and $0.03 \%$, respectively. FEPS inhibited mushroom tyrosinase with the half maximal inhibitory concentration $\left(\mathrm{IC}_{50}\right)$ of $16.5 \mathrm{mg} / \mathrm{ml}$ and dose-dependently inhibited cellular tyrosinase activity $(63.9 \%$ at $50 \mu \mathrm{g} / \mathrm{ml}$, and $83.3 \%$ at $100 \mu \mathrm{g} / \mathrm{ml}$ ) in the cell-free extract of SK-MEL-5 human melanoma cell and $\alpha$-melanocytestimulating hormone $(\alpha-\mathrm{MSH})$-stimulated melanin formation in intact SK-MEL-5 human melanoma cell. The $\mathrm{IC}_{50}$ of FEPS against NO production from RAW264.7 macrophage cells was $42.8 \pm 0.64 \mu \mathrm{g} / \mathrm{ml}$. By in vivo study using a zebrafish model, exposure of FEPS at $400 \mu \mathrm{g} / \mathrm{ml}$ to dechorionated zebrafish embryos for $18 \mathrm{~h}$ decreased the pigment density, compared to that without FEPS-treated control.

Keywords: Fomitopsis castanea, exopolysaccharides, SK-MEL-5 human melanoma cells, zebrafish, tyrosinase

\section{Introduction}

Mushrooms are known as functional foods because of their bioactive compounds that are considered beneficial for human health [1]. The biological and pharmaceutical activities of mushroom are due to cellular and secondary metabolite compounds, which have been extracted from the fruiting body and cultured mushroom medium [1]. Exopolysaccharides (EPS) are secondary metabolite polymers that are secreted into the culture medium by microorganism during the growth process. EPS are used in foods, pharmaceuticals, biomedical, and cosmetic industries because of their biological and pharmaceutical activities such as tyrosinase inhibitory activity [2], hepatoprotective effect, antioxidant activity, immunomodulation property $[3,4]$, anti-inflammatory [5], antitumor, antidiabetic, antimicrobial, and/or immune-stimulatory activities [6] and prebiotic effect [7]. EPS are composed of repeating units of monosaccharides joined by glycosidic linkages [8]. The structure of EPS varies in different species, due to the different of monosaccharides and glycosyl linkages in their repeating unit. These differences in EPS structure affect their biological function $[9,10]$. The fungal EPS are easier to isolate, purify, and cheaper to produce in vast quantity and less time compared to EPS prepared from fruiting bodies $[9,10]$.

Melanogenesis is the process for the production of melanin, enhanced by melanogenic enzymes such as tyrosinase and related proteins, for protecting the skin from UV irradiation [11, 12]. However, overproduction of melanin can cause aesthetic problems [13]. Tyrosinase catalyzes the hydroxylation of L-tyrosine and the oxidation of 3,4-dihydroxy-L-phenylalanine (L-DOPA) [14], and then the polymerization of pigments [15]. Thus, tyrosinase 
inhibitors can be used as skin-brightening agents in cosmeceuticals $[11,16]$.

Fomitopsis castanea is a type of wood-decay medicinal fungi species [17]. The purification and characterization of EPS from F. castanea have been reported [17]. That study focused on the determination of EPS structure and in vitro fermentation of EPS in a simulated intestinal environment. The main monosaccharides of EPS from $F$. castanea were arabinose, mannose, rhamnose, galactose, and glucose [17]. Adding EPS to the fermentation system of the simulated intestinal environment increased the production of shortchain fatty acid content in the fecal extract of tested human [17]. However, there has been no report of the melanogenesis inhibitory effects and anti-inflammatory activity of EPS from $F$. castanea. In this regard, we isolated EPS from submerged culture of $F$. castanea mycelia (FEPS) and found that FEPS inhibited melanin biosynthesis and tyrosinase activity. Furthermore, using SK-MEL-5 human melanoma cells and zebrafish, the FEPS inhibited melanogenesis and tyrosinase activity both in vitro and in vivo, respectively. Therefore, FEPS have the potential to be used as a natural, functional tyrosinase inhibitor in cosmetic application.

\section{Materials and Methods}

\section{Screening of Exopolysaccharides from Different Fungal Species} against Mushroom Tyrosinase

The lyophilized culture supernatants from Abortiporus biennis, Cryptoporus volvatus, Fomitopsis castanea, Phallus luteus, Pholiota alnicola, and Pholiota limonella mycelia were obtained from the Korea National Institute of Biological Resources (NIBR, Korea). The crude EPS from 6 fungal species were prepared by adding $400 \mu \mathrm{l}$ chilled ethanol to $8 \mathrm{mg}$ of cell-free supernatant powder for overnight at $4^{\circ} \mathrm{C}$. Samples were then centrifuged at 3,200 $\times g$ for $30 \mathrm{~min}$ at $4^{\circ} \mathrm{C}$. The protein was removed using the Sevag method [18]. Briefly, chloroform and n-butyl alcohol (4:1, v/v) were added to exopolysaccharides, then the mixture was vigorously mixed at vortices for $30 \mathrm{~min}$, and centrifuged at 5,700 $\times g$ for $20 \mathrm{~min}$. The supernatants were carefully transferred to new Eppendorf tubes. The inhibitory effect of EPS against mushroom tyrosinase was carried out using reaction mixture containing $10 \mathrm{U} / \mathrm{ml}$ mushroom tyrosinase (Sigma, USA), $3.3 \mathrm{mM} \mathrm{L-DOPA} \mathrm{(Sigma),} \mathrm{and} \mathrm{10 \%} \mathrm{of}$ fungal EPS in $50 \mathrm{mM}$ potassium phosphate buffer $(\mathrm{pH}$ 6.8) for $10 \mathrm{~min}$ at $25^{\circ} \mathrm{C}$. The absorbance of the reaction was measured at $475 \mathrm{~nm}$ using a SpectroMax M3 microplate reader (Molecular Devices, USA).

Preparation of Exopolysaccharides from $F$. castanea Using Submerged Culture Fermentation

F. castanea was grown on potato dextrose agar (PDA) medium in a Petri dish at $25^{\circ} \mathrm{C}$ for 7 days. Then, F. castanea was transferred to the seed culture broth, by punching out $5 \mathrm{~mm}$ of the agar culture using a sterilized cork borer. The seed culture was grown in $200 \mathrm{ml}$ DY media containing $2 \%(\mathrm{w} / \mathrm{v})$ dextrose and $0.2 \%(\mathrm{w} / \mathrm{v})$ yeast extract in a $500 \mathrm{ml}$ flask at $25^{\circ} \mathrm{C}$ at $150 \mathrm{rpm}$ for 7 days. Next, $10 \%(\mathrm{v} / \mathrm{v})$ of the seed culture was transferred into $1 \mathrm{~L}$ culture media in a $1.6 \mathrm{~L}$ stirred-tank fermenter (Hanil Inc., Korea) at $25^{\circ} \mathrm{C}$ and $150 \mathrm{rpm}$ for 18 days. The culture broth from the fermenter was filtered through $110 \mathrm{~mm}$ diameter filter paper (Whatman No. 5, Camlab., UK). The culture filtrate was then precipitated with four volumes of cold absolute ethanol, stirred vigorously, and kept overnight at $4^{\circ} \mathrm{C}$. After centrifugation at 3,369 $\times g$ for $30 \mathrm{~min}$ at $4^{\circ} \mathrm{C}$, the precipitated EPS was dissolved in water, and then deproteinated by the Sevag method. The deproteinized polysaccharides were lyophilized at $-10^{\circ} \mathrm{C}$ under $10 \mathrm{~Pa}$ (Eyela FD550, Japan), and stored at $-20^{\circ} \mathrm{C}$ for further study. The extraction yield of FEPS was calculated by weighing lyophilized precipitates centrifuged from cell-free culture [19]. The protein concentration in FEPS was determined by using Bradford assay with bovine serum (BSA) as standard. Briefly, samples or BSA standards (0.1 $1.0 \mathrm{mg} / \mathrm{ml}$ ) were added to a 96-well plate containing $200 \mu \mathrm{l}$ of dye reagent (Bio-Rad Protein Assay kit II, Bio-Rad, USA) and mixed for $2 \mathrm{~min}$. After $5 \mathrm{~min}$ at room temperature, the absorbance was read at $595 \mathrm{~nm}$ using a SpectraMax M3.

\section{Identification of Monosaccharides of Exopolysaccharide}

EPS (1 mg) was hydrolyzed using $0.5 \mathrm{M}$ hydrochloric acid at $121^{\circ} \mathrm{C}$ for $30 \mathrm{~min}$ in a vial for the quantification and identification of monosaccharides. The monosaccharide composition of EPS was determined by thin layer chromatography (TLC). One $\mu$ l of acid hydrolysate was spotted on a precoated silica gel $60 \mathrm{~F}_{254}$ TLC (Merck, Germany) with glucose, galactose, mannose, rhamnose, and arabinose as standards [17]. The TLC plates were developed five times with acetonitrile: water $(85: 15, \mathrm{v} / \mathrm{v})$ solvent system. The carbohydrates were then visualized by dipping the plates into a solvent mixture of $0.3 \%(\mathrm{w} / \mathrm{v}) \mathrm{N}-(1-N a p h t h y l)$ ethylenediamine dihydrochloride and $5 \%(\mathrm{v} / \mathrm{v}) \mathrm{H}_{2} \mathrm{SO}_{4}$ in methanol, followed by $7 \mathrm{~min}$ of heating at $121^{\circ} \mathrm{C}$. The amount of monosaccharides in EPS was analyzed by conversion of integrated density values (IDV) using the AlphaEaseFC 4.0 program (Alpha Inotech, USA).

Mushroom Tyrosinase Inhibition Assay of EPS from F. castanea The inhibition activity of FEPS against mushroom tyrosinase was carried out as in our previous study [20]] with kojic acid as a positive control. Assays were completed as above with FEPS concentration from $0-20 \mathrm{mg} / \mathrm{ml}$. The absorbance of the reaction was measured at $475 \mathrm{~nm}$ using a SpectraMax M3.

\section{Cell Cytotoxicity Tests}

SK-MEL-5 human melanoma cells and RAW264.7 mouse macrophage cells were obtained from the Korean Cell Line Bank (Korea) and maintained in RPMI 1640 and Dulbecco's modified Eagle's medium, fetal bovine serum purchased from GenDEPOT (USA), and penicillin and streptomycin purchased from Invitrogen 
(USA) at $37^{\circ} \mathrm{C}$ in $5 \% \mathrm{CO}_{2}[21,22]$. Cells grown in a 96 -well plate at $2 \times 10^{4}$ cells/well were treated with various concentrations of FEPS $(0-250 \mu \mathrm{g} / \mathrm{ml})$ or $\beta$-arbutin $(156.3-2,500 \mu \mathrm{M})$ at $37^{\circ} \mathrm{C}$ for $24 \mathrm{~h}$. Then, $90 \mu \mathrm{l}$ of culture medium was mixed with $10 \mu \mathrm{l}$ of EzCyTox solution purchased from DOGEN (Korea). After $1 \mathrm{~h}$ at $37^{\circ} \mathrm{C}$, plates were measured at $450 \mathrm{~nm}$ using a SpectraMax M3. Percent viability was determined as cell viability relative to the control.

\section{Cellular Tyrosinase Activity Assay}

SK-MEL-5 human melanoma cells grown in a 6-well plate at $2 \times$ $10^{5}$ cells/well were treated with different concentrations of FEPS $(50-100 \mu \mathrm{g} / \mathrm{ml})$ or $\beta$-arbutin $(1-2 \mathrm{mM})$ and $500 \mathrm{nM}$ alphamelanocyte stimulating hormone ( $\alpha$-MSH) for 24 h. $150 \mu \mathrm{M}$ kojic acid were used as a positive control. Then, the cells were harvested after trypsin treatment and washed twice with ice-cold PBS. The cell pellet was obtained by centrifugation at $12,600 \times g$ for $10 \mathrm{~min}$ and lysed in $50 \mathrm{mM}$ PBS containing $1 \%$ Triton X-100 on ice for $30 \mathrm{~min}$ at $4^{\circ} \mathrm{C}$. Lysates were cleared by centrifugation at $12,600 \times g$ for $20 \mathrm{~min}$ at $4^{\circ} \mathrm{C}$. The protein concentration in the supernatant was determined using Bio-Rad DC protein assay, with bovine serum albumin as a standard. The reaction mixture consisted of cell-extracted protein $(10 \mu \mathrm{g}), 2.5 \mathrm{mM}$ L-DOPA in $50 \mathrm{mM}$ PBS buffer ( $\mathrm{pH} \mathrm{6.8)}$ ) at $37^{\circ} \mathrm{C}$ for $1 \mathrm{~h}$. The oxidation of LDOPA was measured at $475 \mathrm{~nm}$ using a SpectraMax M3. Activity was calculated using the following formula: Tyrosinase activity $(\%)=\left(\mathrm{OD}_{475}\right.$ of sample $/ \mathrm{OD}_{475}$ of control $) \times 100$.

\section{Measurement of Nitric Oxide Production}

Nitric oxide production was determined as described previously [23]. RAW264.7 cells grown on a 96-well plate at $2 \times 10^{4}$ cells/well for $48 \mathrm{~h}$ were treated with FEPS at a concentration from 1.56$200 \mu \mathrm{g} / \mathrm{ml}$ with $1 \mu \mathrm{g}$ LPS $/ \mathrm{ml}$ for $24 \mathrm{~h}$ and $100 \mu \mathrm{M}$ indomethacin was used as a positive control. Then, culture supernatant $(80 \mu \mathrm{l})$ was mixed with Griess reagent $(80 \mu \mathrm{l})$ for $20 \mathrm{~min}$. The absorbance was measured at $540 \mathrm{~nm}$ using a SpectraMax M3. The amount of nitrite in the sample was calculated from a standard curve prepared with a sodium nitrite standard curve of $(0-500) \mu \mathrm{M}$ in the cell culture medium.

\section{Zebrafish Experiments}

Zebrafish eggs were obtained from the Zebrafish Center for Disease Modeling (ZCDM, Korea).

Zebrafish embryos were allocated in a 6-well plate, with 3 embryos/well of triplicate groups, containing $2 \mathrm{ml}$ of embryo medium, which consisted of $5.03 \mathrm{mM} \mathrm{NaCl}, 0.17 \mathrm{mM} \mathrm{KCl}$, $0.33 \mathrm{mM} \mathrm{CaCl}_{2} \cdot 2 \mathrm{H}_{2} \mathrm{O}, 0.33 \mathrm{mM} \mathrm{MgSO}_{4} \cdot 2 \mathrm{H}_{2} \mathrm{O}$, and $0.00001 \%(\mathrm{w} / \mathrm{v})$ methylene blue. At $36 \mathrm{~h}$ post fertilization (hpf), FEPS of (100 and 400) $\mu \mathrm{g} / \mathrm{ml}$ was treated to each well containing dechorionated zebrafish embryos, and phenotype-based evaluations of antimelanogenic effects were performed. 1-phenyl-2-thiourea (PTU) and kojic acid (Sigma) were used as positive controls. At $54 \mathrm{hpf}$, embryos were transferred to the glass bottom for observation and photography of the effect on the pigmentation of zebrafish under a Leica M205FA (Leica Microsystems, Germany) stereoscope in the National Instrumentation Center for Environment Management (NICEM, Seoul National University, Korea). The quantification of melanin pigmentation was conducted by measuring the estimated raw integrated density on zebrafish embryos using Image J software (National Institutes of Health, USA). The experimental protocols in this study were carried out with zebrafish larvae up to $54 \mathrm{hpf}$ and therefore are not subject to the regulations of the Institutional Animal Care and Use Committee.

\section{Statistical Analysis}

Experiments were conducted in triplicate, and the data were shown as mean \pm standard error of the mean (SEM). Statistical analysis was done using one-way ANOVA and Tukey post hoc multiple comparison tests on GraphPad Prism 8.0.2 (GraphPad Software, USA).

\section{Results}

\section{Inhibitory Effect of Different Fungal Exopolysaccharides against Mushroom Tyrosinase}

The crude EPS from 6 fungal species were examined for tyrosinase inhibitory activity. The crude EPS were extracted by ethanol and deproteinized by the Sevag method. The aqueous fractions were collected. The mushroom tyrosinase

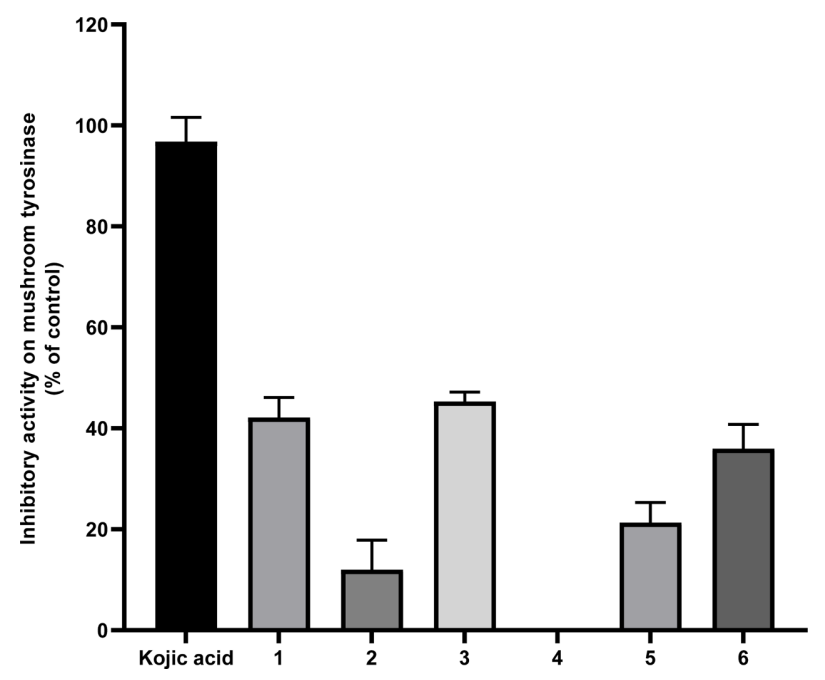

Fig. 1. Inhibitory activity of the exopolysaccharides from different fungal EPS against mushroom tyrosinase.

EPS extracted from 1: Abortiporus biennis, 2: Cryptoporus volvatus, 3: Fomitopsis castanea, 4: Phallus luteus, 5: Pholiota alnicola, 6: Pholiota limonella. The inhibitory effect of exopolysaccharides against mushroom tyrosinase were carried out at reaction mixture containing $10 \mathrm{U} / \mathrm{ml}$ mushroom tyrosinase, $3.3 \mathrm{mM}$ L-DOPA, and 10\% of fungus exopolysaccharides in $50 \mathrm{mM}$ postassium phosphate buffer $(\mathrm{pH}$ 6.8) for $10 \mathrm{~min}$ at $25^{\circ} \mathrm{C}$. 
inhibitory effects of EPS that was extracted from lyophilized culture supernatants from Abortiporus biennis, Cryptoporus volvatus, Fomitopsis castanea, Phallus luteus, Pholiota alnicola, and Pholiota limonella mycelia were shown in Fig. 1. Except for the EPS from Phallus luteus, the other EPS inhibited mushroom tyrosinase activity of $1-45 \%$ of original activity (Fig. 1). Among them, EPS from Fomitopsis castanea (FEPS) showed the strongest inhibitory effect against mushroom tyrosinase, and FEPS were selected for further biochemical studies.

\section{Production of Fomitopsis castanea Exopolysaccharides Using Submerged Culture}

The extraction yield of FEPS was $213.1 \mathrm{mg} / \mathrm{l}$ in DY media containing $2 \%(\mathrm{w} / \mathrm{v})$ dextrose and $0.2 \%(\mathrm{w} / \mathrm{v})$ of yeast extract. The concentration of protein in FEPS was $0.03 \%$.

\section{Monosaccharide Composition of Fomitopsis castanea Exopolysaccharides}

After acid hydrolysis, monosaccharide composition was determined by TLC analysis (Fig. 2). Comparing the $R_{f}$ value of standard compounds obtained from TLC analysis,

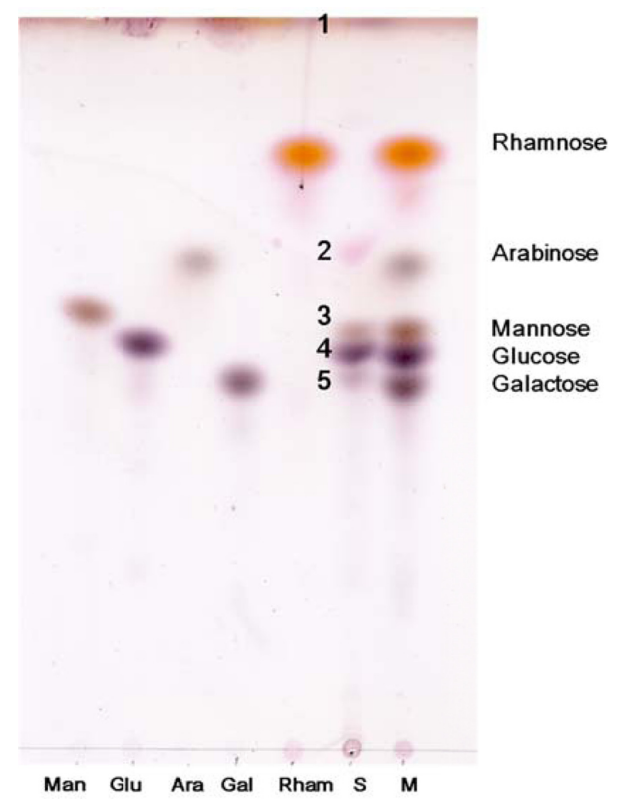

Fig. 2. Thin-layer chromatogram of monosaccharide composition of the EPS extract from Fomitopsis castanea.

Man: mannose; Glu: glucose; Ara: arabinose; Gal: galactose; Rham: rhamnose; S: acid hydrolysate of FEPS; M: standard mixtures (mannose, glucose, arabinose, galactose, rhamnose). FEPS (1 mg) were hydrolyzed by $0.5 \mathrm{M}$ hydrochloric acid at $121^{\circ} \mathrm{C}$ for $30 \mathrm{~min}$ in a vial. The monosaccharide composition was analyzed using TLC with five ascents of acetonitrile/water $(85: 15, \mathrm{v} / \mathrm{v})$.
FEPS from Fomitopsis castanea were composed of galactose $(16.8 \%)$, glucose $(34.5 \%)$, and mannose $(25.8 \%)$ as predominant sugars (Table S1).

\section{Mushroom Tyrosinase Inhibitory Effect}

The details of the inhibitory effect against mushroom tyrosinase activity of FEPS of $0-20 \mathrm{mg} / \mathrm{ml}$ were studied (Fig. S1). FEPS at 10, 12, 14, 16, and $20 \mathrm{mg} / \mathrm{ml}$ inhibited this activity by $18.6,27.4,32.4,43.8$, and $72.4 \%$, respectively. The $\mathrm{IC}_{50}$ of FEPS against mushroom tyrosinase was determined as $16.5 \mathrm{mg} / \mathrm{ml}$. FEPS inhibited mushroom tyrosinase in a dose-dependent way.
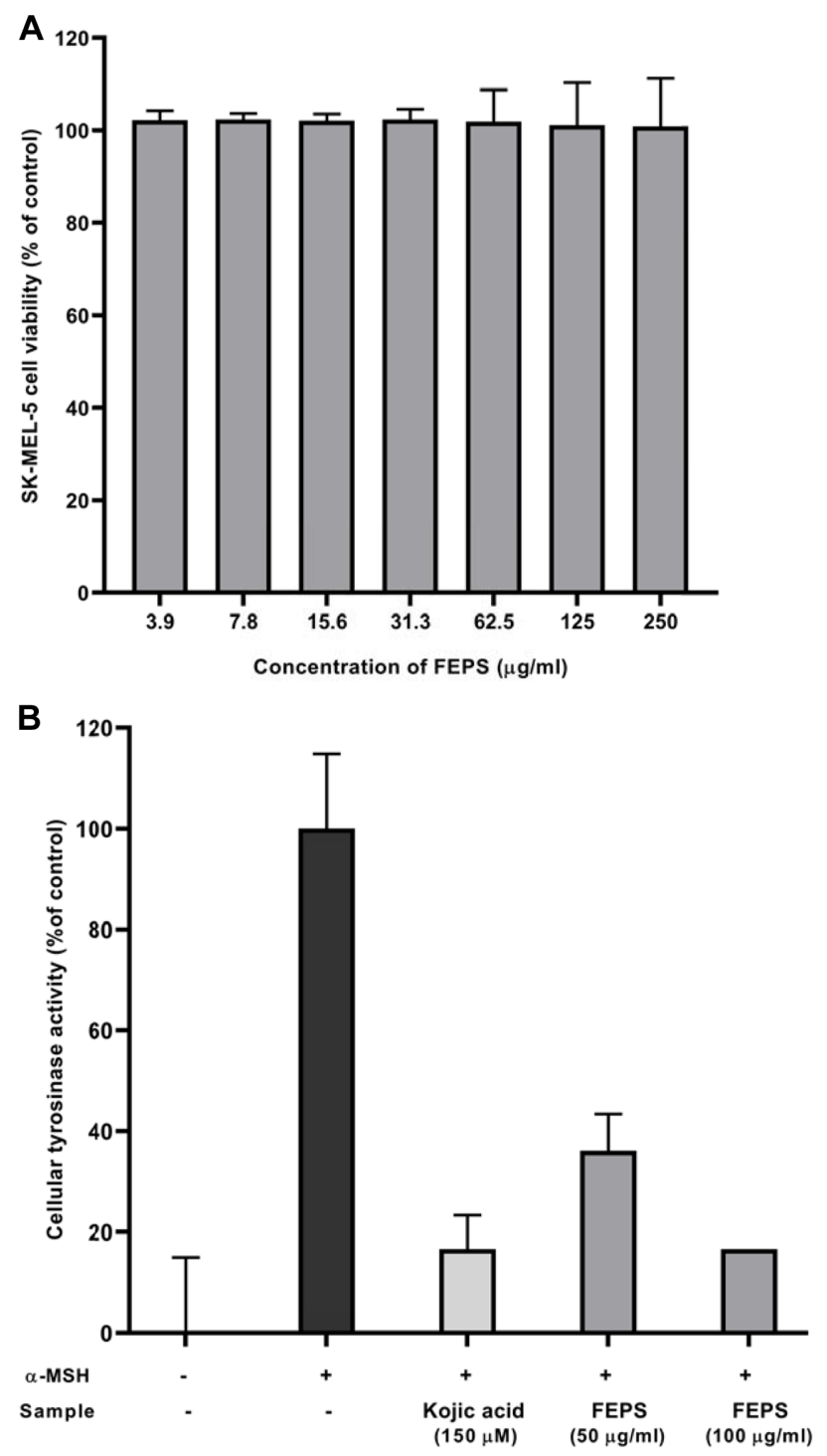

Fig. 3. Cell viability (A), and cellular tyrosinase (B) on SKMEL-5 human melanoma cells of EPS from F. castanea mycelial culture supernatants. 


\section{Cellular Tyrosinase Activity on SK-MEL-5 Human Melanoma Cells}

Arbutin is currently used in the cosmetic industry as a skin brightening agent because it shows strong inhibition against tyrosinase from mushroom, mouse, and human [24, 25]. Thus, arbutin was selected as a positive control for this experiment. Cell viabilities of SK-MEL-5 human melanoma cells were shown in Fig. 3A. Since the cells exhibited a survival rate of over $95 \%$ at $250 \mu \mathrm{g} / \mathrm{ml}$ (Fig. 3A), the cellular tyrosinase was conducted with concentration ranging (50-150) $\mu \mathrm{g} / \mathrm{ml}$. $\alpha$-MSH was used to study the inhibitory effects of FEPS on the cellular tyrosinase expression level in SK-MEL-5 cells. The cellular tyrosinase activity of cells treated with $\alpha$-MSH was assigned as $100 \%$. Incubation for $24 \mathrm{~h}$ with FEPS of 50 or $100 \mu \mathrm{g} / \mathrm{ml}$ or kojic acid of $150 \mu \mathrm{M}$ resulted in tyrosinase inhibition of $63.9 \%$, $83.3 \%$, or $83.3 \%$, respectively (Fig. $3 \mathrm{~B}$ ). $\beta$-arbutin did not show any cytotoxicity under assay condition (Fig. S2A). The inhibitory activity of $1-2 \mathrm{mM} \beta$-arbutin after $24 \mathrm{~h}$ incubation was $87.2 \%$ and $91.5 \%$, respectively.

\section{Inhibition of Nitric Oxide Production in LPS-Stimulated RAW 264.7 Cells}

In this study, we investigated whether FEPS acted as an inhibitor or scavenger for nitric oxide (NO) and as an inflammatory mediator released from lipopolysaccharideinduced mouse macrophage cell model [26]. Production of NO was investigated after lipopolysaccharide (LPS) stimulation. Since the cells exhibited a survival rate of over $95 \%$ at $200 \mu \mathrm{g} / \mathrm{ml}$ (Fig. 4A), the inhibition of NO production in LPS-stimulated RAW264.7 cells was conducted from $3.125-200 \mu \mathrm{g} / \mathrm{ml}$ (Fig. 4B). LPS led to an increase in NO production when compared with the negative control, but FEPS at concentration of $3.125-200 \mu \mathrm{g} / \mathrm{ml}$ caused a reduction in NO production in a dose-dependent manner when compared with the negative control. In detail, the inhibitory effect on producing NO in RAW264.7 treated with FEPS at concentrations of 3.125, 6.25, 12.5, 25, 50, 100, and $200 \mu \mathrm{g} / \mathrm{ml}$ for $24 \mathrm{~h}$ were $12.5 \pm 0.8 \%, 13.8 \pm 2.1 \%, 21.3$ $\pm 3.8 \%, 40.1 \pm 1.5 \%, 53.9 \pm 0.2 \%, 63.6 \pm 0.8 \%$, and $71.6 \pm 0.9 \%$ as compared to the group treated with LPS only, respectively. The $\mathrm{IC}_{50}$ of FEPS against NO production from RAW264.7 macrophage cells was $42.8 \pm 0.64 \mu \mathrm{g} / \mathrm{ml}$ (Fig. 4B).

\section{Evaluation of Melanogenic Inhibitory Effect Using the Zebrafish Model}

Dechorionated zebrafish embryos at $36 \mathrm{hpf}$ were incubated with FEPS at 100 and $400 \mu \mathrm{g} / \mathrm{ml}$, and $10 \mathrm{mM}$ kojic acid and $0.2 \mathrm{mM}$ PTU as positive control (Fig. 5A). The FEPS at
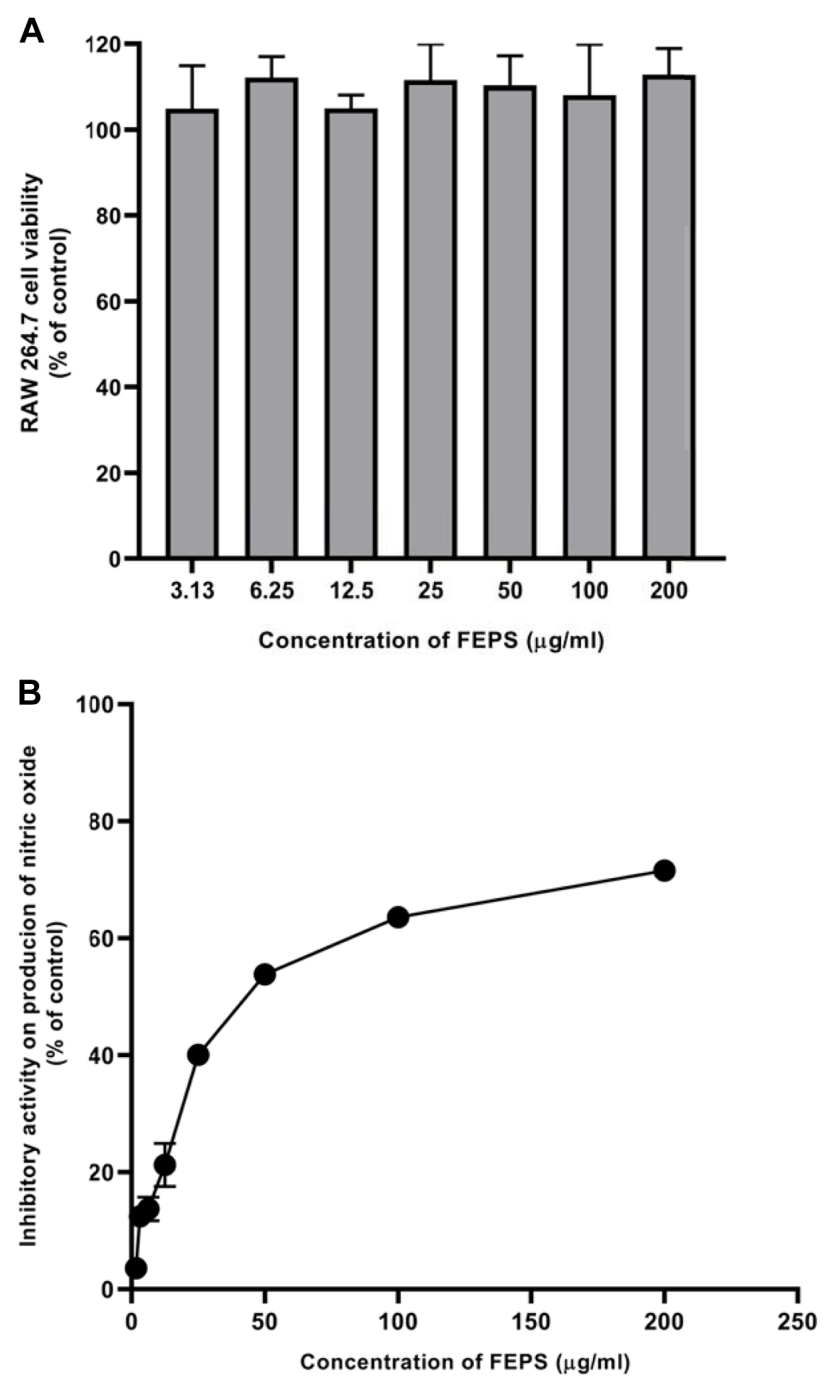

Fig. 4. Cell viability (A), and nitric oxide production (B) on RAW264.7 cells of EPS from F. castanea mycelial culture supernatants.

$400 \mu \mathrm{g} / \mathrm{ml}$ significantly decreased the pigmentation of dechorionated zebrafish embryos (Fig. 5B). There are no reports on the antimelanogenesis effect of EPS on zebrafish embryos.

\section{Discussion}

Melanin plays an important role in the determination of eye, skin, hair color and human skin homeostasis, such as protection against ultraviolet irradiation, chemicals and scavenging toxic drugs [27]. However, abnormal accumulation of melanin in the skin as hyperpigmented spots affects its appearance. To treat skin and pigment abnormalities, many 
A

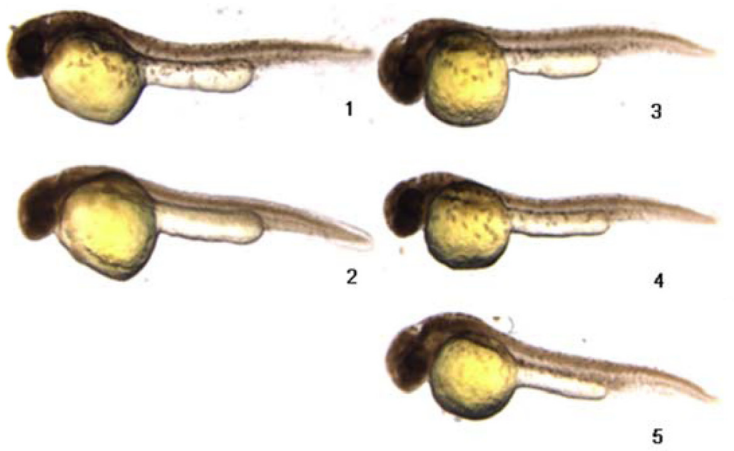

B

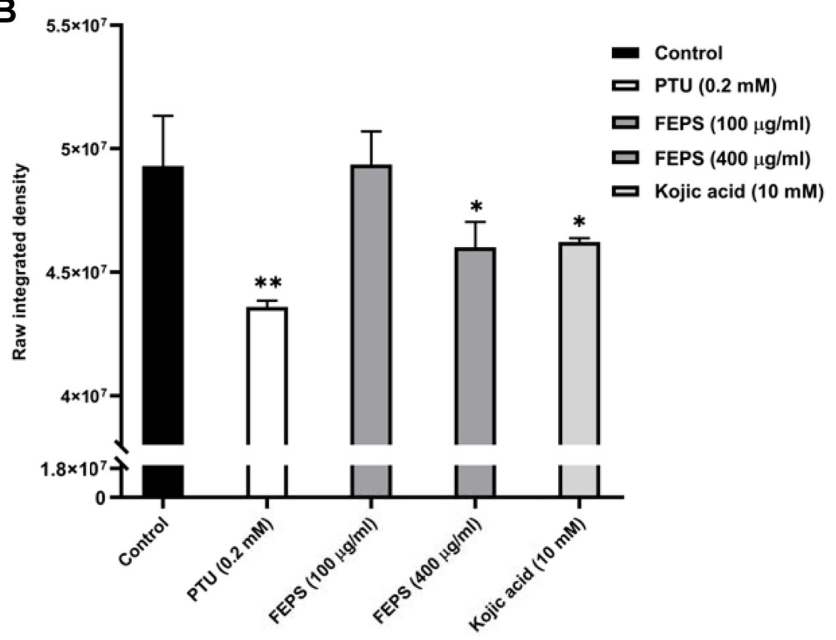

Fig. 5. Effect of EPS from F. castanea mycelial culture supernants on melanin synthesis in zebrafish (A) and the quantification of melanin pigmentation was conducted using Image J software $(\mathbf{B})$.

Dechorionated zebrafish embryos were treated from (36-54) hpf with $10 \mathrm{mM}$ kojic acid, $0.2 \mathrm{mM}$ PTU, and 100 and $400 \mu \mathrm{g} / \mathrm{ml} \mathrm{FEPS}$, and the effects on pigmentation were assessed using a stereomicroscope. (1; control, 2; $0.2 \mathrm{mM}$ PTU, 3; $400 \mu \mathrm{g} / \mathrm{ml} \mathrm{FEPS,} \mathrm{4;} 100 \mu \mathrm{g} / \mathrm{ml} \mathrm{FEPS,} \mathrm{5;}$ $10 \mathrm{mM}$ kojic acid) (B) ${ }^{*} p<0.1,{ }^{* *} p<0.05$ was considered as statistically significant compared with the control.

brightening agents have been reported and applied in cosmeceutical, food, and pharmaceutical industries. The natural inhibitors against tyrosinase have increased because safety is strictly monitored in the food and cosmetic industries. In this study, we examined antimelanogenesis of 6 different fungal exopolysaccharides. Among them, EPS from Fomitopsis castanea was selected due to its high tyrosinase inhibitory activity. According to our best knowledge, this is the first study demonstrating antimelanogenesis of exopolysaccharides from Fomitopsis castanea. The type of strain, medium components, and physical conditions maintained during fermentation have effects on the amount of polysaccharide production, the composition of final products, structure, molecular weight, and functional properties of EPS [9, 28, 29]. The protein concentration in FEPS is lower than that in FEPS extracted by Guo and Chi [17]. The predominant sugars of FEPS in this study were galactose $(16.8 \%)$, glucose $(34.5 \%)$, and mannose (25.8\%) while Guo and Chi reported that EPS from Fomitopsis castanea mainly consists of rhamnose (43.4\%), arabinose $(0.09 \%)$, mannose $(0.13 \%)$, glucose $(51.32 \%)$, and galactose (5.06\%) [17].

There are various factors that affected the monosaccharide content in exopolysaccharides such as monosaccharide composition [30, 31], metal ions [32], aeration rate, agitation speed, $\mathrm{pH}$, temperature [33,34]. Even with the same strain, the chemical composition and quality of EPS are also influenced by conditions such as nutrient status and growth phase [35]. In some cases, one strain can produce different exopolysaccharides with different molecular weight; Bacillus thermoantarcticus synthesized two different EPSs, one of these was mainly composed of mannose and glucose in a ratio of 1:0.7, and the other was a mannan [36]. In this study, we used DY media containing $2 \%(\mathrm{w} / \mathrm{v})$ dextrose and $0.2 \%(\mathrm{w} / \mathrm{v})$ of yeast extracted, while Guo and Chi used 1\% (w/v) peptone, $1 \%(\mathrm{w} / \mathrm{v})$ beef extract, $5 \%(\mathrm{w} / \mathrm{v})$ yeast extract, $2 \%(\mathrm{w} / \mathrm{v})$ glucose, $0.1 \%(\mathrm{v} / \mathrm{v})$ Tween-80, $0.5 \%(\mathrm{w} / \mathrm{v})$ sodium acetate, $0.2 \%(\mathrm{w} / \mathrm{v})$ diammonium citrate, $0.2 \%(\mathrm{w} / \mathrm{v})$ dipotassium phosphate, $0.058 \%(\mathrm{w} / \mathrm{v})$ of magnesium sulfate, and $0.025 \%(\mathrm{w} / \mathrm{v})$ of manganese sulfate [17]. In addition, we used crude exopolysaccharides to analyze monosaccharide content instead of purified EPS as reported by Guo and Chi [17]. Therefore, the different monosaccharide content of EPS from Fomitopsis castanea between our finding and the previous repost [17] was possibly the result of various culture conditions.

Mushroom tyrosinase and $\alpha$-MSH-stimulated SK-MEL-5 human melanoma cells are used extensively for antimelanogenesis studies of FEPS. In melanocytes, FEPS inhibited cellular tyrosinase in a dose-dependent manner (Fig. 3B). Keratinocytes and other cells around melanocytes release several melanogenic factors, such as a nitric oxide (NO) in response to proinflammatory cytokines [37]. In human melanocytes, NO donors have been reported to increase tyrosinase activity and melanin synthesis [37]. The cyclic guanosine $3^{\prime}-5^{\prime}$-monophosphate (cGMP) pathway is reported to be a major mechanism for NO-induced melanogenesis for the up-regulation of tyrosinase gene expression [38]. NO was demonstrated as a paracrine mediator of UVinduced melanogenesis [37]. Although $\mathrm{NO}$ has been reported to play a beneficial role in the physiological 
process, such as the regulation of neuronal communication [39], they can also react with oxygen, produce reactive molecules, and aggressively attack biomolecules, resulting in inflammation [39, 40]. We found that FEPS inhibit the making of NO in LPS-stimulated RAW264.7 macrophages cells. However, further studies are needed to evaluate the activation of the intracellular signaling pathways of FEPS. We also examined the antimelanogenesis effect of FEPS through an in vivo test using zebrafish embryos. The zebrafish embryo is a general vertebrate model system for biochemical research with high physiological and genetic correspondence to mammals in terms of melanocytes and melanosomes. In addition, they are also small in size, easy to handle, have many offspring each generation, and absorb drugs efficiently through their skin and gills [41, 42]. Therefore, zebrafish embryos can replace animal subjects in animal experiments [41-43]. Melanin pigments can be detected on the zebrafish surface, allowing simple observation of the pigmentation process [44]. Amounts of 100 and $400 \mu \mathrm{g} / \mathrm{ml}$ of FEPS were added to each well containing dechorionated zebrafish embryos and at $400 \mu \mathrm{g} / \mathrm{ml}$ of FEPS decreased significantly the pigmentation of the embryos. FEPS could effectively reduce melanogenesis via suppression of tyrosinase activity in zebrafish.

\section{Acknowledgments}

This work was partially supported by the OTTOGI Corporation through the Research and Publication Project, by the Korean Institute of Planning and Evaluation for Technology in Food, Agriculture, Forestry, and Fisheries (IPET) through the Agriculture, Food and Rural Affairs Research Center Support Program, funded by the Ministry of Agriculture, Food, and Rural Affairs (MAFRA) (D. Kim, 710012-03-1-HD220), Republic of Korea. The present study has been also conducted under the research grants (2018R1D1A1A09083366, D. Kim) of NRF, Republic of Korea.

\section{Conflict of Interest}

The authors have no financial conflicts of interest to declare.

\section{References}

1. Wasser SP. 2011. Current findings, future trends, and unsolved problems in studies of medicinal mushrooms. Appl. Microbiol. Biotechnol. 89: 1323-1332.

2. Bajpai VK, Rather IA, Park YH. 2016. Partially purified exopolysaccharide from Lactobacillus Sakei Probio 65 with antioxidant, $\alpha$-glucosidase and tyrosinase inhibitory potential. J. Food Biochem. 40: 264-274.

3. Wang HX, Ng TB, Liu WK, Ooi VEC, Chang ST. 1996. Polysaccharide-peptide complexes from the cultured mycelia of the mushroom Coriolus versicolor and their culture medium activate mouse lymphocytes and macrophages. Int. J. Biochem. Cell B. 28: 601-607.

4. Lee JS, Cho JY, Hong EK. 2009. Study on macrophage activation and structural characteristics of purified polysaccharides from the liquid culture broth of Hericium erinaceus. Carbohydr. Polym. 78: 162-168.

5. Cheng JJ, Lin CY, Lur HS, Chen HP, Lu MK. 2008. Properties and biological functions of polysaccharides and ethanolic extracts isolated from medicinal fungus, Fomitopsis pinicola. Process Biochem. 43: 829-834.

6. Patel M, Patel U, Gupte S. 2018. Production of exopolysaccharide (EPS) and its application by new fungal isolates SGMP1 and SGMP2. Int. J. Environ. Agric. Res. 7: 511-523.

7. Al-Manhel AJA. 2017. Production of exopolysaccharide from local fungal isolate. Curr. Res. Nutr. Food Sci. 5: 338-346.

8. Alves MJ, Ferreira I, Martins A, Pintado M. 2012. Antimicrobial activity of wild mushroom extracts against clinical isolates resistant to different antibiotics. J. Appl. Microbiol. 113: 466475 .

9. Mahapatra S, Banerjee D. 2013. Fungal exopolysaccharide: production, composition and applications. Microbiol. Insights. 6: 1-16.

10. Orlandelli RC, Vasconcelos AFD, Azevedo JL, Corradi da Silva ML, Pamphile JA. 2016. Screening of endophytic sources of exopolysaccharides: preliminary characterization of crude exopolysaccharide produced by submerged culture of Diaporthe sp. JF766998 under different cultivation time. Biochim. Open. 2: 33-40.

11. Kim YJ, Uyama H. 2005. Tyrosinase inhibitors from natural and synthetic sources: structure, inhibition mechanism and perspective for the future. Cell Mol. Life. Sci. 62: 1707-1723.

12. Zhang $X, \mathrm{Hu} X$, Hou A, Wang H. 2009. Inhibitory Effect of 2,4,2', 4'-tetrahydroxy-3-(3-methyl-2-butenyl)-chalcone on tyrosinase activity and melanin biosynthesis. Biol. Pharm. Bull. 32: 86-90.

13. Briganti S, Camera E, Picardo M. 2003. Chemical and instrumental approaches to treat hyperpigmentation. Pigment Cell Res. 16: 101-110.

14. Arung ET, Shimizu K, Kondo R. 2006. Inhibitory effect of artocarpanone from Artocarpus heterophyllus on melanin biosynthesis. Biol. Pharm. Bull. 29: 1966-1969.

15. Hao L, Sheng Z, Lu J, Tao R, Jia S. 2016. Characterization and antioxidant activities of extracellular and intracellular polysaccharides from Fomitopsis pinicola. Carbohydr Polym. 141: 54-59.

16. Singh BK, Kim EK. 2019. P-protein: a novel target for skinwhitening agent. Biotechnol. Bioprocess Eng. 24: 76-84. 
17. Guo WK, Chi YJ. 2017. Purification and fermentation characteristics of exopolysaccharide from Fomitopsis castaneus Imaz. Int. J. Biol. Macromol. 105: 213-218.

18. Peng Y, Han B, Liu W, Zhou R. 2016. Deproteinization and structural characterization of bioactive exopolysaccharides from Ganoderma sinense mycelium. Sep. Sci. Technol. 51: 359-369.

19. Lim J-M, Yun J-W. 2006. Enhanced production of exopolysaccharides by supplementation of toluene in submerged culture of an edible mushroom Collybia maculata TG-1. Process Biochem. 41: 1620-1626.

20. Woo HJ, Kang HK, Thi THN, Kim GE, Kim YM, Park JS, et al. 2012. Synthesis and characterization of ampelopsin glucosides using dextransucrase from Leuconostoc mesenteroides B-1299CB4: glucosylation enhancing physicochemical properties. Enzyme Microb. Technol. 51: 311-318.

21. Kim HJ, Lee HJ, Park MK, Gang KJ, Byun HJ, Park JH, et al. 2014. Involvement of transglutaminase-2 in alpha-MSHinduced melanogenesis in SK-MEL-2 human melanoma cells. Biomol. Ther. (Seoul) 22: 207-212.

22. Cho UM, Choi DH, Yoo DS, Park SJ, Hwang HS. 2019. Inhibitory effect of ficin derived from fig latex on inflammation and melanin production in skin cells. Biotechnol. Bioprocess Eng. 24: 288-297.

23. Hur J, Nguyen TTH, Park N, Kim J, Kim D. 2018. Characterization of quinoa (Chenopodium quinoa) fermented by Rhizopus oligosporus and its bioactive properties. $A M B$ Express. 8: 143.

24. Maeda K, Fukuda M. 1996. Arbutin: mechanism of its depigmenting action in human melanocyte culture. $J$. Pharmacol. Exp. Ther. 276: 765-769.

25. Funayama M, Arakawa $H$, Yamamoto R, Nishino T, Shin T, Murao S. 1995. Effects of alpha- and beta-arbutin on activity of tyrosinases from mushroom and mouse melanoma. Biosci. Biotechol. Biochem. 59: 143-144.

26. Chiou S-Y, Ha C-L, Wu P-S, Yeh C-L, Su Y-S, Li M-P, et al. 2015. Antioxidant, anti-tyrosinase and anti-inflammatory activities of oil production residues from Camellia tenuifloria. Int. J. Mol. Sci. 16: 29522-29541.

27. Lee $\mathrm{CH}, \mathrm{Wu} \mathrm{SB}$, Hong CH, Yu HS, Wei YH. 2013. Molecular mechanisms of UV-induced apoptosis and its effects on skin residential cells: the implication in UV-based phototherapy. Int. J. Mol. Sci. 14: 6414-6435.

28. Nicolaus B, Kambourova M, Oner ET. 2010. Exopolysaccharides from extremophiles: from fundamentals to biotechnology. Environ. Technol.31: 1145-1158.

29. Poli A, Di Donato P, Abbamondi GR, Nicolaus B. 2011. Synthesis, production, and biotechnological applications of exopolysaccharides and polyhydroxyalkanoates by Archaea. Archaea 2011:693253.

30. Wu ZW, Yang ZJ, Gan D, Fan JL, Dai ZQ, Wang XQ, et al. 2014. Influences of carbon sources on the biomass, production and compositions of exopolysaccharides from Paecilomyces hepiali HN1. Biomass Bioenergy 67: 260-269.
31. Peng L, Li J, Liu Y, Xu ZH, Wu JY, Ding ZY, et al. 2016. Effects of mixed carbon sources on galactose and mannose content of exopolysaccharides and related enzyme activities in Ganoderma lucidum. RSC Adv. 6: 39284-39291.

32. Zhao W, Chai DD, Li HM, Chen T, Tang YJ. 2014. Significance of metal ion supplementation in the fermentation medium on the structure and anti-tumor activity of Tuber polysaccharides produced by submerged culture of Tuber melanosporum. Process Biochem. 49: 2030-2038.

33. Xu CP, Kim SW, Hwang HJ, Yun JW. 2006. Production of exopolysaccharides by submerged culture of an enthomopathogenic fungus, Paecilomyces tenuipes C240 in stirred-tank and airlift reactors. Bioresour. Technol. 97: 770-777.

34. Peng L, Qiao SK, Xu ZH, Guan F, Ding ZY, Gu ZH, et al. 2015. Effects of culture conditions on monosaccharide composition of Ganoderma lucidum exopolysaccharide and on activities of related enzymes. Carbohydr. Polym. 133: 104-109.

35. AW D. 1990. Microbial exopolymer secretions in open ocean environments: their role(s) in food webs and marine progresses. Oceanogr. Mar. Biol. 28: 73-153.

36. Manca MC, Lama L, Improta R, Esposito E, Gambacorta A, Nicolaus B. 1996. Chemical composition of two exopolysaccharides from Bacillus thermoantarcticus. Appl. Environ. Microbiol. 62: 3265-3269.

37. Roméro-Graillet C, Aberdam E, Clément M, Ortonne JP, Ballotti R. 1997. Nitric oxide produced by ultravioletirradiated keratinocytes stimulates melanogenesis. J. Clin. Invest. 99: 635-642.

38. Dong Y, Wang H, Cao J, Ren J, Fan R, He X, et al. 2011. Nitric oxide enhances melanogenesis of alpaca skin melanocytes in vitro by activating the MITF phosphorylation. Mol. Cell. Biochem. 352: 255-60.

39. Joo T, Sowndhararajan K, Hong S, Lee J, Park SY, Kim S, et al. 2014. Inhibition of nitric oxide production in LPSstimulated RAW 264.7 cells by stem bark of Ulmus pumila L. Saudi. J. Biol. Sci. 21: 427-435.

40. Nappi A, Vass E. 2001. The effects of nitric oxide on the oxidations of 1-dopa and dopamine mediated by tyrosinase and peroxidase. J. Biol. Chem. 276: 11214-22.

41. MacRae CA, Peterson RT. 2015. Zebrafish as tools for drug discovery. Nat. Rev. Drug Discov. 14: 721-731.

42. Tabassum N, Tai HM, Jung DW, Williams DR. 2015. Fishing for nature's hits: establishment of the zebrafish as a model for screening antidiabetic natural products. Evid. Based Complement. Alternat. Med. 2015: 287847.

43. Choi TY, Kim JH, Ko DH, Kim CH, Hwang JS, Ahn S, et al. 2007. Zebrafish as a new model for phenotype-based screening of melanogenic regulatory compounds. Pigment Cell Res. 20: 120-127.

44. Colanesi S, Taylor KL, Temperley ND, Lundegaard PR, Liu D, North TE, et al. 2012. Small molecule screening identifies targetable zebrafish pigmentation pathways. Pigment Cell Melanoma Res. 25: 131-143. 